\title{
Impact of Early Spring Weather Factors on the Risk of Tomato Spotted Wilt in Peanut
}

R. O. Olatinwo and J. O. Paz, Department of Biological and Agricultural Engineering, University of Georgia, Griffin 30223; and S. L. Brown, Department of Entomology, R. C. Kemerait, Jr. and A. K. Culbreath, Department of Plant Pathology, and G. Hoogenboom, Department of Biological and Agricultural Engineering, University of Georgia, Tifton 31793

\begin{abstract}
Olatinwo, R. O., Paz, J. O., Brown, S. L., Kemerait, R. C., Jr., Culbreath, A. K., and Hoogenboom, G. 2009. Impact of early spring weather factors on the risk of tomato spotted wilt in peanut. Plant Dis. 93:783-788.

Peanut growers in the southeastern United States have suffered significant economic losses due to spotted wilt caused by Tomato spotted wilt virus (TSWV). The virus is transmitted by western flower thrips, Frankliniella occidentalis, and tobacco thrips, F. fusca, and was first reported in the southeast in 1986. The severity of this disease is extremely variable in individual peanut fields, perhaps due to the sensitivity of the vector population to changing weather patterns. The objective of this study was to investigate the impact of early spring weather on spotted wilt risk in peanut. On-farm surveys of spotted wilt severity were conducted in Georgia peanut fields in 1998, 1999, 2002, 2004, and 2005. The percent spotted wilt intensity (\%) for cv. Georgia Green was recorded and categorized into three intensity levels: low, moderate, and high. Meteorological data were obtained from the Georgia Automated Environmental Monitoring Network for the period between March 1 and April 30. Statistical analysis was conducted to identify weather variables that had significant impact on spotted wilt intensity. The results indicated a high probability of spotted wilt if the number of rain days during March was greater than or equal to 10 days and planting was before 11 May or after 5 June. The total evapotranspiration in April ( $>127$ $\mathrm{mm})$ and the average daily minimum temperature in March $\left(>6.8^{\circ} \mathrm{C}\right)$ similarly increased the risk of spotted wilt. Knowing in advance the level of spotted wilt risk expected in a peanut field could assist growers with evaluating management options and significantly improve the impact of their decisions against spotted wilt risk in peanut.
\end{abstract}

Significant economic losses have been reported by peanut (Arachis hypogaea L.) growers since spotted wilt caused by the Tomato spotted wilt virus (TSWV) (family Bunyaviridae) was first observed in the southeastern United States in $1986(11,17)$. Common foliar symptoms in peanut include stunting, chlorotic spots, concentric rings, necrotic spots, and yellowing (31). Western flower thrips, Frankliniella occidentalis (Pergande), and tobacco thrips, Frankliniella fusca (Hinds), are the major vectors associated with the transmission of TSWV in peanut fields in the southeastern United States (4). In North Carolina, between 25 and $50 \%$ incidence of TSWV infections were reported in tomato, tobacco, and pepper fields in 2002 (15). In Georgia, the total reduction in the value of

Corresponding author: R. O. Olatinwo

E-mail: olatinwo@uga.edu

Accepted for publication 2 April 2009.

doi:10.1094/PDIS-93-8-0783

(C) 2009 The American Phytopathological Society peanut due to damage associated with TSWV was estimated at $\$ 31.7$ million in 2005 (21).

According to Lewis (28), the impact of thrips infestation of a crop depends on the suitability of weather conditions for population growth, among many other factors. The link between rainfall and temperature and thrips and spotted wilt development has been documented in several studies $(3,9,18,32)$. Heavy rainfall was reported to have a negative effect on thrips larvae survival (22) and adult flight (28), whereas increased temperatures during the spring was associated with greater thrips activity and population growth $(22,28,29,38)$. Harding (18) suggested that cool temperatures and rains are detrimental to thrips colonization on onions in south Texas. Thrips often migrate into cropping fields during the spring after overwintering on uncultivated plants or alternative hosts $(15,22,28,38)$. Hence, the timing of peanut emergence in relation to the movement of viruliferous thrips vectors into a cultivated field can significantly affect the incidence of TSWV for the remainder of the season (12).
Stormy weather conditions have been linked to mass flights of thrips. Weather fronts and incipient thunderstorms have been reported to discourage the mass flight of thrips, thereby resulting in high densities above the soil surface due to the thrips' landing attempts (23,25-28). Another study found that the number of thrips captured in flight has a positive relationship with the number of wet days or days with precipitation (35). In peanut, populations of the adult thrips vectors $F$. occidentalis and $F$. fusca were reported to be greater for early planting in April or late planting in June compared with planting in May $(33,39)$. At the same time, there was a higher level of spotted wilt associated with early- and late-planted peanut compared with those planted during the middle of the planting season (4-6).

Current practices for managing spotted wilt in peanut rely on the use of a preseason TSWV risk index developed by scientists at the University of Georgia. The risk index assesses the spotted wilt risk levels associated with production practices in order to help growers avoid high-risk situations (4). The index has seven components that include cultivar, planting date, plant population, type of insecticide application, row pattern, tillage system, and presence or absence of Classic herbicide (Chlorimuron ethyl; E.I. DuPont, Wilmington, DE) application (4-6). The TSWV risk index had varied successes over the years across Georgia peanutproducing areas, as indicated by the development and validation data obtained by Brown et al. (4). However, the current formulation of the index does not include a weather component, nor does it account for the preseason weather parameters for predicting the expected level of spotted wilt intensity.

The focus of this study was to build on a previous study (36) which utilized regression techniques to identify important weather variables and variable combinations with TSWV risk index for predicting spotted wilt severity in peanut. The hypothesis that early spring weather parameters affect TSWV risk index accuracy, presumably due to the impact of weather 
conditions on thrips vector (viruliferous) activities and development, was examined. The objective of this study was to use the early spring weather variables previously correlated with spotted severity of the previous study (36) and the TSWV risk index components for estimating the expected spotted wilt intensity based on a recursive partitioning modeling approach.

Recursive partitioning is a nonparametric modeling approach that is suitable for investigating the effect of TSWV risk index components and preseason weather variables and their interactions on the expected probability of spotted wilt intensity. Paul and Munkvold (37) used a similar modeling approach to predict severity in gray leaf spot. Delalieux et al. (13) also illustrated the application of the technique in a study on biotic stress (Venturia inaequalis) in apple trees. The accuracy of this approach can be evaluated with the receiver operating characteristic (ROC) curve, which has been used in blossom blight forecasts with MARYBLYT and Cougarblight (14) for comparison of the risk indicators for Sclerotinia spp. control in oilseed rape (30), and for evaluating the predictors of apple scab (40).

\section{MATERIALS AND METHODS}

Survey. Historical survey data obtained during the 1998, 1999, 2002, 2004, and 2005 growing seasons were used in this study. In total, 188 peanut fields were surveyed in the peanut-growing region of Georgia during five growing seasons (Tables 1 and 2). The number of peanut fields in the survey varied by growing season due to the availability of peanut fields and variability in cultural practices employed by different growers. The planting dates ranged from 16 April to 26 May 1998, 14 April to 6 June 1999, 8 April to 31 May 2002, 13 May to 10 June 2004, and 25 April to 20 June 2005.

Assessment of spotted wilt was conducted on four randomly selected plots at each farm location prior to digging. Plants were evaluated for symptoms of spotted wilt using a disease intensity rating that represents a combination of incidence and severity. The number of $0.3-\mathrm{m}$ portions of row containing severely stunted, chlorotic, wilted, or dead plants due to TSWV was counted for each plot and converted to a percentage of the total row length. Visually distinct reductions in height or width of the peanut row were required before portions of row would be considered severely affected with regard to stunting $(4,8)$. The observed percent spotted wilt intensity was classified into three groups: (i) low = less than $20 \%$, (ii) moderate $=$ greater than or equal to $20 \%$ but less than $40 \%$; and (iii) high $=$ greater than or equal to $40 \%$, based on previous spotted wilt intensity observed in growers' field relative to yield loss (unpublished data). Runner-type peanut cv. Georgia Green, released in 1996 (2), was selected for this study. Georgia Green is a cultivar moderately susceptible to TSWV during the survey period, accounting for more than $60 \%$ of the total peanut acreage.

Components of TSWV risk index used in this study include planting date, plant population, insecticide use, row pattern, and tillage. The peanut planting date was categorized as (i) Prior to 1 May, (ii) 1 to 10 May, (iii) 11 to 25 May, (iv) 26 May to 5 June, or (v) after 5 June. The peanut plant population was categorized as (i) less than three plants per $30.5 \mathrm{~cm}$, (ii) three to four plants per $30.5 \mathrm{~cm}$, or (iii) more than four plants per $30.5 \mathrm{~cm}$. The type of insecticide application at planting was categorized as (i) no insecticide application, (ii) application of Phorate (Thimet 20G), or (iii) other insecticides. The type of row pattern employed was categorized as (i) single row or (ii) twin row and the tillage method was categorized as (i) conventional tillage or (ii) reduced tillage, according to the 2005 risk index categorization (6).

Meteorological data. Meteorological data were obtained from the Georgia Automated Environmental Monitoring Network (AEMN; www.georgiaweather.net), and was the most widely grown cultivar

using the AEMN weather station nearest to each peanut field location that was surveyed. The AEMN $(19,20)$ is an automated network of 77 weather stations that collect air and soil temperature, barometric pressure, solar radiation, wind speed and direction, rainfall, relative humidity, and soil moisture. The sensors of each station are scanned at a one-second frequency and, every $15 \mathrm{~min}$, a summary is calculated and stored in the data logger.

The period between 1 March and 30 April was defined as early spring in this study. The daily weather data that were obtained from the AEMN were used to calculate the various derived weather variables. These included a separate average minimum and maximum air temperature for March and April, the accumulated rainfall for March and April, and the number of rain days for the months of March and April. A "rain day" was considered to be a day with accumulated rainfall greater than $0.25 \mathrm{~mm}$. A description of weather variables that were used in this study is presented in Table 3 and includes a few modifications to a previous study (36). The daily temperatures for March and April were separated for the two months (TavM, TminM, TmaxM, TavA, TminA, and TmaxA) to evaluate the effect of the individual weather variables for each month. The chilling hours variable for the month of April (ChillHrA) was calculated as the number of hours when the air temperature was below $7.2^{\circ} \mathrm{C} \quad\left(45^{\circ} \mathrm{F}\right)$. The total evapotranspiration in April (EVTA) was obtained using an AEMN calculator based on direct evaporation from wet surfaces and the release of water vapor by vegetation. The water balance for April (WBA) was derived from the differences between evapotranspiration and accumulated precipitation in April.

Table 2. Descriptive summary of the spotted wilt intensity rating on peanut surveyed in Georgia over five growing seasons

\begin{tabular}{ccccccc}
\hline Year & $\begin{array}{c}\text { Spotted wilt } \\
\text { intensity }(\boldsymbol{\%})\end{array}$ & $\begin{array}{c}\text { Standard } \\
\text { deviation }\end{array}$ & $\begin{array}{c}\text { Standard } \\
\text { error of mean }\end{array}$ & $\begin{array}{c}\text { Minimum } \\
\mathbf{( \% )}\end{array}$ & $\begin{array}{c}\text { Maximum } \\
(\boldsymbol{\%})\end{array}$ & $\begin{array}{c}\text { No. of fields } \\
\text { surveyed }\end{array}$ \\
\hline 1998 & 13.9 & 11.1 & 2.3 & 2.4 & 42.0 & 24 \\
1999 & 11.8 & 15.7 & 1.9 & 0.5 & 90.5 & 66 \\
2002 & 28.4 & 24.5 & 3.6 & 0.6 & 87.8 & 46 \\
2004 & 36.3 & 18.5 & 4.6 & 4.3 & 63.0 & 16 \\
2005 & 42.3 & 24.1 & 4.0 & 6.8 & 90.3 & 36 \\
\hline
\end{tabular}

Table 1. Summary of surveyed counties and planting dates the during multiyear survey of spotted wilt intensity in Georgia

\begin{tabular}{|c|c|c|c|}
\hline Year & Name of county surveyed ${ }^{a}$ & Planting date & $\begin{array}{l}\text { No. of fields } \\
\text { surveyed }\end{array}$ \\
\hline 1998 & Burke, Colquitt, Decatur, Dooly, Early, Screven, Tift & 16 April-26 May & 24 \\
\hline 1999 & $\begin{array}{l}\text { Baker, Barrien, Brooks, Bulloch, Burke, Colquitt, Dooly, Emanuel, Evans, Grady, Irwin, Laurens, Miller, } \\
\text { Randolph, Screven, Seminole, Sumter, Tattnall, Toombs }\end{array}$ & 14 April-6 June & 66 \\
\hline 2002 & $\begin{array}{l}\text { Bulloch, Burke, Candler, Colquitt, Crisp, Decatur, Early, Jefferson, Jenkins, Laurens, Macon, Mitchell, } \\
\text { Randolph, Seminole, Taylor, Terrell, Turner }\end{array}$ & 8 April-31 May & 46 \\
\hline 2004 & Appling, Bulloch, Burke, Dodge, Evans, Mitchell & 13 May-10 June & 16 \\
\hline 2005 & $\begin{array}{l}\text { Appling, Ben Hill, Candler, Coffee, Cook, Early, Grady, Miller, Pulaski, Seminole, Sumter, Terrell, Tift, } \\
\text { Toombs }\end{array}$ & 25 April-20 June & 36 \\
\hline
\end{tabular}

${ }^{a}$ Number of peanut fields included in the survey varied by growing season and county due to the availability of peanut fields and variability in cultural practices (e.g., crop rotation employed by different growers). 
Statistical analysis. A modification of the existing TSWV risk index was outside the scope of this current study. Therefore, the statistical analysis focused mainly on the expected probability of spotted wilt from the interactions between the TSWV risk index components and early spring weather variables identified in the previous study (36). For practical applications, low and high spotted wilt intensities were assumed to be of greater interest to the growers for management plans and to avoid high-risk situations. Therefore, the expected probability of spotted wilt intensity for the extremes (low or high) were analyzed using the recursive partition analysis platform JMP 7.01 (JMP; SAS Institute, Cary, NC).

Recursive partitioning is a classification and regression tree-fitting methodology used for exploring variable relationships and modeling continuous and discrete responses. The method partitions data according to a relationship between the independent variables and the response or dependent variable. It examines all combinations of possible splits and picks maximum statistically significant splits. A split is a partition of data that finds a cut or grouping of independent variable $(X)$ value that best predicts a dependent variable $(Y)$ value. The maximized significance criterion option in JMP was used for categorical splits. The option calculates significance values for each split candidate according to the LogWorth, which is the negative $\log$ of the adjusted $P$ value (LogWorth $=-\log _{10}[P$ value $\left.]\right)$. Only the candidate with the maximum LogWorth is selected for the split. Variables excluded from splits based on the LogWorth are not significant. A split is chosen to maximize the difference in the responses between the two branches of the split.

The estimated probability for each categorical response level (low or high) becomes the fitted value, and the most significant split is determined by the largest likelihood-ratio $\chi^{2}$, reported as $G^{2}$. The best model was selected based on the $R^{2}$ value using the split history option. Terminal nodes were pruned if the improved $R^{2}$ was minimal or insignificant in order to avoid overfitting. The recursive partitioning method deals relatively well with interactions and collinearity compared with linear procedures (24).

The recursive partition output includes an ROC curve to evaluate the predictive quality of the partitioning model. An ROC curve is a graphical plot of the true positive rate (TPR) as a function of the false positive rate (FPR) at all possible decision thresholds of the prediction algorithm (41). The decision threshold determines the specificity and sensitivity of a predictive system. Lower thresholds will increase the sensitivity but also increase the FPR (decrease specificity), while higher thresholds will reduce the FPR (increase specificity) but also decrease sensitivity. Sensitivity is the number of true positives (TPs) divided by the total number of actual positives (Ps), or the true positives ratio (TPR), while the false positive ratio (FPR) is the number of called false positives (FPs) divided by the total number of actual negatives (Ns). Sensitivity is the ability to correctly estimate the risk level, while specificity is the ability to avoid FPs (sensitivity $=\mathrm{TPR} ; 1-$ specificity $=$ FPR $)$. A prediction algorithm is produced from a tree methodology to clarify the results from the recursive partitioning. The decision wilt intensity was set at a probability $>50 \%$. A terminal node was classified as the group with probability $>50 \%$.

The Kappa statistic $(1,10)$, obtained from the contingency analysis with JMP, was used to determine the degree of agreement between the prediction of the model and the actual spotted wilt intensity classification (low or high). It is expressed by the equation $\kappa=\operatorname{Pr}(a)-\operatorname{Pr}(e) / 1-$ $\operatorname{Pr}(e)$, where $\operatorname{Pr}(a)$ is the relative observed agreement and $\operatorname{Pr}(e)$ is the hypothetical probability of chance agreement. If the model and the actual observation are in complete agreement, then $\kappa=1$; if there is no agreement, then $\kappa \leq 0$. The magnitude of the coefficient reflects the strength of the agreement.

\section{RESULTS}

A decision tree was generated for low and high risk levels using recursive partitioning with the corresponding probability value. The partitioning resulted in a total of eight terminal nodes (scenarios) with different combinations of predictors and varying probability of low or high spotted wilt intensity. These were the end scenarios that were reached at the completion of an algorithm path (Fig. 1).

The results showed a $100 \%$ expected probability of high spotted wilt intensity when the number of rain days in March threshold for either low or high spotted

was greater than or equal to 10 days and peanut was not planted between 11 May and 5 June (no. 1). With the same number of rain days, the probability decreased to $30 \%$ when planting was between 11 and 25 May (no. 2). Similarly, there was a $100 \%$ expected probability of high intensity when the number of rain days in March was less than 10, the amount of evapotranspiration in April was greater than or equal to $127 \mathrm{~mm}$, and the plant population was less than three plants per $30.5 \mathrm{~cm}$ in a row (no. 3). However, when the plant population was greater or equal to 3 plants per $30.5 \mathrm{~cm}$ in a row, the probability of high spotted wilt intensity reduced to $20 \%$ (no. 4). Differences in average daily minimum temperature in April affected spotted wilt intensity based on the interactions with the other variables of the model (nos. 5 and 6). There was a $100 \%$ expected probability of high spotted wilt when the average daily minimum temperature in March was greater than or equal to $6.8^{\circ} \mathrm{C}$. Scenario no. 8 indicated a $96 \%$ expected probability of low intensity when the number of rain days in March was less than 10, the total evapotranspiration in April was less than $127 \mathrm{~mm}$, and the planting was on or after 1 May. The risk of spotted wilt increased when the field was planted before 1 May. However, the application of a strip tillage system (no. 7) reduced the risk (Fig. 1).

The $G^{2}$ value (Table 4 ) and the position of a predictor variable from the top of the decision tree moving down through the branches to terminal nodes indicates the variable's importance in predicting the probability of spotted wilt intensity. Weather variables with significant contribution ( $G^{2}$ value) include the total evapotranspiration in April (29.9), the number of rainy days in March (26.7), and the average daily minimum temperature in March (11.2). The TSWV risk index components with significant contributions include planting date, plant population, and the tillage system (Table 4).

Table 3. Weather variables during early spring that were used in this study to analyze the risk of spotted wilt on peanut

\begin{tabular}{ll}
\hline Variable & \multicolumn{1}{c}{ Description } \\
\hline Planting date & Planting date \\
Population & Plant population \\
Insecticide & Insecticide applications \\
Row & Row pattern \\
Tillage & Tillage pattern \\
TmaxM & Average maximum daily temperature in March $\left({ }^{\circ} \mathrm{C}\right)$ \\
TminM & Average minimum daily temperature in March $\left({ }^{\circ} \mathrm{C}\right)$ \\
TavM & Average daily temperature in March $\left({ }^{\circ} \mathrm{C}\right)$ \\
TmaxA & Average maximum daily temperature in April $\left({ }^{\circ} \mathrm{C}\right)$ \\
TminA & Average minimum daily temperature in April $\left({ }^{\circ} \mathrm{C}\right)$ \\
TavA & Average daily temperature in April $\left({ }^{\circ} \mathrm{C}\right)$ \\
RainfallM & Accumulated rainfall in March $(\mathrm{mm})$ \\
RainDayM & Number of rain days in March \\
RainfallA & Accumulated rainfall in April $(\mathrm{mm})$ \\
RainDayA & Number of rain days in April \\
ChillHrA & Number of chilling hours in April $\left(\mathrm{Base}=7.2^{\circ} \mathrm{C}\right)$ \\
EVTA & Total evapotranspiration in April $(\mathrm{mm})$ \\
WBA & Water balance in April (mm) \\
\hline
\end{tabular}


The area under the ROC curve was used to evaluate the model for specificity and sensitivity. It is an indicator of the goodness of fit, and varies between 0.5 (no predictive value) and 1 (perfect fit). In other words, it represents the sorting efficiency of the model. An area greater than 0.5 indicates that more observations are correctly classified than incorrectly classified according to the algorithm, whereas an area less than or equal to 0.5 indicates that more observations are incorrectly classified than correctly classified and the model is not meaningful. In this study, the area under the ROC curve (Fig. 2) was 0.95 for low and 0.95 for high, which indicates that observations were $95 \%$ correctly classified and 5\% incorrectly classified for both levels according to the algorithm, indicating that the model was able to discriminate between low and high spotted wilt categories accurately based on the available data.

The Kappa statistic showed that, after seven splits of recursive partitioning, the model with weather variables had a higher degree of agreement with the actual survey of spotted wilt intensity (0.84) compared with the model without weather variables (0.54). A nominal logistic model of TSWV risk index components, used in the study that excluded weather variables, had a lower (0.46) degree of agreement com- pared with the actual survey of spotted wilt intensity. These results, therefore, indicate that the inclusion of weather variables significantly improved the prediction ability of the model.

\section{DISCUSSION}

In this study, we examined the impact of weather parameters during early spring on the expected probability of spotted wilt intensity in Georgia Green, a peanut cultivar that is widely grown in the southeastern United States. Preseason weather conditions favoring large populations of viruliferous vectors are particularly important for successful transmission of plant viruses. The results showed that the number of rainy days in March, the total evapotranspiration in April, and the aver- age daily minimum temperature in March were significantly associated with spotted wilt intensity. The decision tree produced from the recursive partitioning revealed that the frequency of rain events in March was a strong predictor of spotted wilt intensity, because it was found in all eight terminal nodes (scenarios) from the splits. A high spotted wilt intensity was associated with the occurrence of more than 10 rainy days in March.

Although heavy rainfall has been shown to have a negative effect on the population of thrips, either through suppression of adult flight (22) or by killing of thrips larvae (28), the potential effects of rain on thrips are complex. In the near term, heavy rainfall can suppress thrips populations by increasing mortality rate, thereby reducing

Table 4. Tomato spotted wilt virus risk index components and early spring weather variables that provided a significant contribution to the spotted wilt intensity probability estimates

\begin{tabular}{lcr}
\hline Term & No. of splits & $\boldsymbol{G}^{\mathbf{2 a}}$ \\
\hline Planting date & 2 & 32.8 \\
Total evapotranspiration in April & 1 & 29.9 \\
Number of rain days in March & 1 & 26.7 \\
Plant population & 1 & 13.0 \\
Average minimum daily temperature in March & 1 & 11.2 \\
Tillage pattern & 1 & 9.0 \\
Total & 7 & 122.6
\end{tabular}

${ }^{a} G^{2}$ values represent the contribution by individual predictor variable in estimating expected probability of spotted wilt intensity.

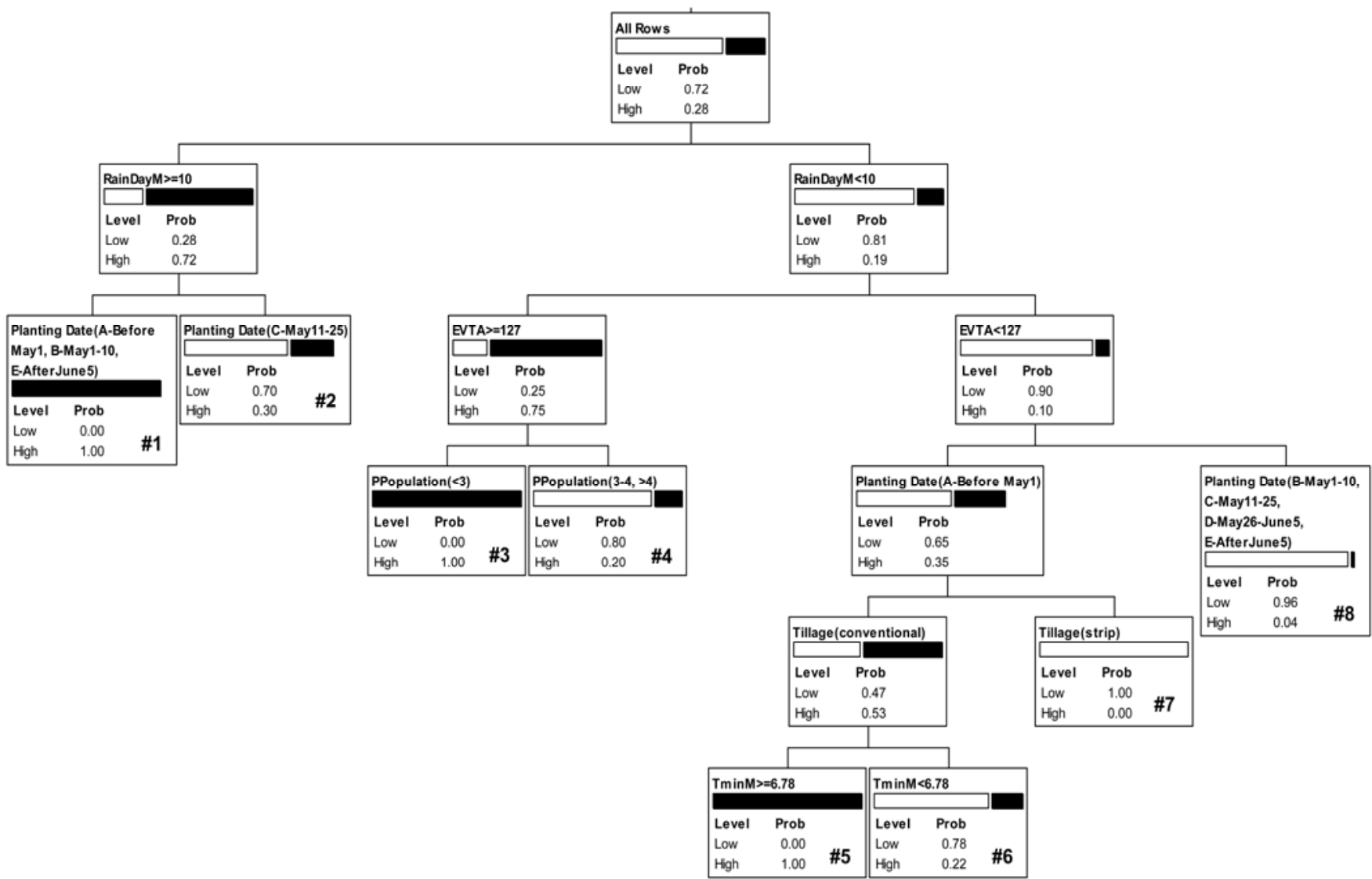

Fig. 1. Decision tree of interactions between some Tomato spotted wilt virus risk index components and early spring weather variables. Presented in each box are the probabilities of a survey result conforming to the specific scenario being classified as low and high. "All rows" indicate that all observations in low and high categories were included in the analysis. 
the population growth rate, or by suppressing flight of adults. However, over a longer term, frequent rains that delay senescence of host plants can also result in higher total thrips populations by prolonging the period of population growth (34). This may partly explain why the risk of spotted wilt was higher when the number of rainy days in March was greater or equal to 10 days compared with when it was less than 10 days (Fig. 1).

It is also possible that the positive effect of frequent rain on thrips populations might offset the negative effect of heavy rain. However, their interactions with other agronomic factors or weather variables, such as evapotranspiration and temperature, that were identified in this study could tip the balance with varying impact on the thrips population. Our results indicated that fewer rainy days in March $(<10$ days) lowered the risk of spotted wilt. However, the risk increased significantly when the total evapotranspiration was higher than $127 \mathrm{~mm}$ in April. A reduction in evapotranspiration could presumably indicate wet soil conditions that are unfavorable for the moisture-sensitive thrips pupae in the soil.

Our results also showed that an average daily minimum temperature below $6.8^{\circ} \mathrm{C}$ during March lowered the intensity of spotted wilt when planting was before 1 May and a conventional tillage system was used. Thrips may become inactive or stop reproducing at this temperature $\left(<6.8^{\circ} \mathrm{C}\right)$, a temperature that is much lower than the optimum temperature required for $\mathrm{F}$. occidentalis $\left(24.5^{\circ} \mathrm{C}\right)$ and $F$. fusca $\left(24.9^{\circ} \mathrm{C}\right)$ oviposition (9). Lewis (28) reported that temperature can potentially affect the reproduction rate of some pest species such as thrips by changing gender ratios. Higher thrips activity and an increase in thrips population growth have been linked to an increase in temperature during the spring in other studies $(22,28,29,38)$. Morsello et al. $(34,35)$ also found that the number of $F$. fusca captured in flight was positively related to degree-days.

Similarly, we have observed a significant correlation between degree-day accumulation and the severity of TSWV on weeds for two locations in Tifton, Tift County, when the minimum-maximum threshold was set between 13.3 and $28.9^{\circ} \mathrm{C}$ (unpublished data). Degree-day measures the total amount of heat required for an organism to develop from one point to another in its life cycle, based on threshold temperatures for that organism (a function of temperature and time); therefore, variation in the average daily minimum temperature would likely influence the amount of accumulated heat, and presumably, alter the rate of thrips development. This situation could partly explain the annual fluctuation in spotted wilt intensity that has been reported in Georgia during the past few years.
These results indicate the possibility that a reduced frequency of rain events in March, a low average daily minimum temperature $\left(<6.8^{\circ} \mathrm{C}\right)$ during March, and a lower total evapotranspiration in April negatively affected the population of dence of TSWV and the dispersing thrips population from winter hosts would be influenced positively by increasing temperature and late spring precipitation that delays senescence of winter annual hosts (34). Brown et al. (3) reported that heavy rains during the last week of March and below-average temperatures during April 2005 led to a high TSWV infection in tobacco until the middle of May in Georgia. Infection of the host could be limited during heavy rain events but other weather conditions may favor thrips development and subsequent spotted wilt development as the interactions indicated.

Groves et al. (16) reported that thrips vectors usually begin dispersing to new hosts (including peanut) in northeastern North Carolina in late March and early April after overwintering on volunteer weed hosts. They noted that the dispersion of TSWV and spread of spotted wilt occurred from April through early June, which coincides with peak fights of $F$. fusca (16). This may differ slightly in the more southern and warmer climate in Georgia compared with North Carolina. thrips. It has been suggested that the inci-

However, several studies have linked the early spring period to thrips-vector population dynamics and subsequent TSWV infections $(15,33,39)$.

Other environmental variables, aside from those included in this study, may also play important roles in spotted wilt intensity on peanut, as previously shown in a 4year study (36) in Georgia. However, in this study, the expected probabilities associated with each interaction between early spring weather variables and TSWV risk index components were presented with different scenarios. The significance of planting date, plant population, and tillage system was clearly identified in the decision tree presented, which showed differences in risk associated with planting dates (scenario nos. 1 and 2), plant population (scenario nos. 3 and 4), and tillage systems (scenario nos. 5, 6, and 7). The expected level of risk was lower for strip tillage, higher plant population, and planting between 11 and 25 May. These results support previous observations by scientists at the University of Georgia (4-7).

Recursive partitioning is a useful prediction rules approach that would be relatively easy for growers to understand and less difficult to implement compared with the regression technique used in a previous study (36). Due to variability in individual peanut field proximity to the nearest AEMN weather station, it is important to

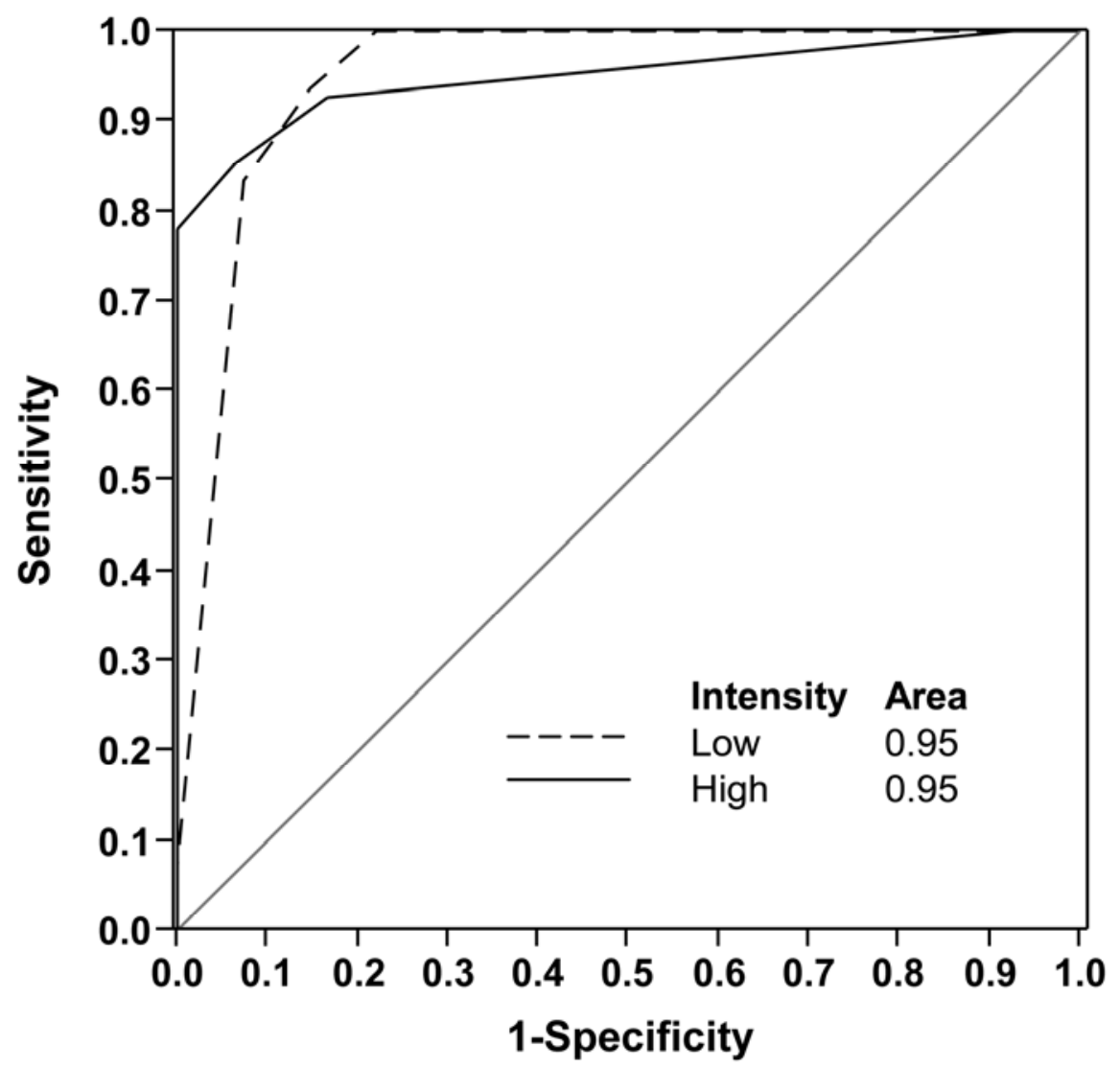

Fig. 2. Receiver operating characteristic curve to determine the accuracy of the decision model in estimating spotted wilt risk on Georgia Green peanut. The true-positive y-axis is labeled "Sensitivity" and the false-positive $\mathrm{x}$-axis is labeled " 1 - Specificity". 
note that some error is inherent in measuring the environmental variables used in the splits. However, availability of a larger survey dataset and corresponding higherresolution weather data could address this and strengthen the model accuracy in the future. The degree of agreement between the model and the survey observations using the Kappa statistic was high (0.84), and the area under the ROC curve indicated that the model was able to discriminate between low and high spotted wilt categories accurately based on the available data. Accurate prediction of expected probability of spotted wilt intensity would enhance growers' decisions in applying appropriate management methods that avoid exposing young plants to spotted wilt risk during the early growth stages (31), thereby reducing the likelihood of economic losses to growers.

\section{ACKNOWLEDGMENTS}

This work was conducted under the auspices of the Southeast Climate Consortium (SECC; http://www.seclimate.org) and supported by a partnership with the United States Department of Agriculture-Risk Management Agency (USDARMA), by grants from the National Peanut Board/Southeast Peanut Research Initiative, the US National Oceanic and Atmospheric AdministrationClimate Program Office (NOAA-CPO) and USDA Cooperative State Research, Education and Extension Services (USDA-CSREES), and by State and Federal funds allocated to Georgia Agricultural Experiment Stations Georgia Agricultural Experiment Stations Hatch project GEO01654. We thank the Spotted Wilt Eradication Action Team (SWEAT) for providing valuable survey data, inputs, and technical support.

\section{LITERATURE CITED}

1. Agresti, A. 1990. Categorical Data Analysis. J. Wiley, New York.

2. Branch, W. D. 1996. Registration of 'Georgia Green' peanut. Crop Sci. 36:806.

3. Brown, S., Csinos, A., Díaz-Pérez, J. C., Gitaitis, R., LaHue, S. S., Lewis, J., Martinez, N., McPherson, R., Mullis, S., Nischwitz, C., Riley, D., Sherwood, J., Sisson, V., Stephenson, M. G., and Wells, L. 2005. Tospoviruses in solanaceae and other crops in the coastal plain of Georgia. Coll. Agric. Environ. Sci. Univ. Ga. Res. Rep. 704:19

4. Brown, S. L., Culbreath, A. K., Todd, J. W., Gorbet, D. W., Baldwin, J. A., and Beasley, J. P. 2005. Development of a method of risk assessment to facilitate integrated management of spotted wilt of peanut. Plant Dis. 89:348356.

5. Brown, S. L., Todd, J. W., Culbreath, A. K., Baldwin, J., Beasley, J., Kemerait, B., Prosko, E., Brenneman, T., Smith, N., Paz, J., Olatinwo, R., Tillman, B., Gorbet, D., Weeks, R., and Hagan, H. 2008. Minimizing disease of peanut in the southeastern United States. In: 2008 Peanut Update. Univ. Ga. Coop. Ext. Serv. Coll. Agric. Environ. Sci. CSS-080114:36-52.

6. Brown, S. L., Todd, J. W., Culbreath, A. K., Baldwin, J., Beasley, J., Kemerait, B., Prosko, Fletcher, S., Smith, N., Woodward, J., Gorbet, D., and Weeks, R. 2005. Minimizing disease of peanut in the southeastern United States. In: 2005 Peanut Update. Univ. Ga. Coop. Ext. Serv. Coll. Agric. Environ. Sci. CSS-050118:36-52.

7. Brown, S. L., Todd, J. W., Culbreath, A. K.,
Baldwin, J. A., Beasley, J. P., and Pappu, H. R. 1999. The tomato spotted wilt risk indexidentifying and avoiding high risk situations. Univ. Ga. Coop. Ext. Serv. Bull. 1165. Athens, GA.

8. Cantonwine, E. G., Culbreath, A. K., Stevenson, K. L., Kemerait, R. C., Jr., Brenneman, T. B., Smith, N. B., and Mullinix, B. G., Jr. 2006. Integrated disease management of leaf spot and spotted wilt of peanut. Plant Dis. 90:493500.

9. Chaisuekul, C., and Riley, D. G. 2005. Host plant, temperature, and photoperiod effects on ovipositional preference of Frankliniella occidentalis and Frankliniella fusca (Thysanoptera: Thripidae). J. Econ. Entomol. 98:21072113.

10. Cohen, J. 1960. A coefficient of agreement for nominal scales. Educ. Psychol. Meas. 20:3746.

11. Culbreath, A. K., Csinos, A. S., Bertrand, P. F., and Demski, J. W. 1991. Tomato spotted wilt virus epidemic in flue-cured tobacco in Georgia. Plant Dis. 75:483-485.

12. Culbreath, A. K., Todd, J. W., and Brown, S. L. 2003. Epidemiology and management of tomato spotted wilt in peanut. Annu. Rev. Phytopathol. 41:54-75.

13. Delalieuxa, S., van Aardtb, J., Keulemansc, W., Schrevensa, E, and Coppina, P. 2007. Detection of biotic stress (Venturia inaequalis) in apple trees using hyperspectral data: Nonparametric statistical approaches and physiological implications. Eur. J. Agron. 27:130143.

14. Dewdney, M. M., Biggs, A. R., and Turechek, W. W. 2007. A statistical comparison of the blossom blight forecasts of MARYBLYT and Cougarblight with receiver operating characteristic curve analysis. Phytopathology 97:1164-1176.

15. Groves, R. L., Walgenbach, J. F., Moyer, J. W., and Kennedy, G. G. 2002. The role of weed hosts and tobacco thrips, Frankliniella fusca, in the epidemiology of Tomato spotted wilt virus. Plant Dis. 86:573-582.

16. Groves, R. L., Walgenbach, J. F., Moyer, J. W., and Kennedy, G. G. 2003. Seasonal dispersal patterns of Frankliniella fusca (Thysanoptera: Thripidae) and tomato spotted wilt virus occurrence in central and eastern North Carolina. J. Econ. Entomol. 96:1-11.

17. Hagan, A. K., Weeks, J. R., French, J. C., Gudauskas, R. T., Mullen, J. M., Gazaway, W. S., and Shelby, R. 1990. Tomato spotted wilt virus in peanut in Alabama. Plant Dis. 74:615.

18. Harding, J. A. 1961. Effect of migration, temperature, and precipitation on thrips infestations in south Texas. J. Econ. Entomol. 54:7779.

19. Hoogenboom, G. 2000. The Georgia automated environmental monitoring network 2000. Pages 24-25 in: Reprints 24th Conf. Agric. For. Meteorol. American Meteorological Society, Boston.

20. Hoogenboom, G., Coker, D. D., Edenfield, J. M., Evans D. M., and Fang, C. 2003. The Georgia Automated Environmental Monitoring Network: 10 years of weather information for water resources management. Pages 896-900 in: Proc. 2003 Ga. Water Resour. Conf. K. J. Hatcher, ed. The University of Georgia, Athens.

21. Kemerait, R. C. 2006. Peanut. In: 2005 Georgia Plant Disease Loss Estimate, compiled by Alfredo Martinez. Univ. Ga. Coll. Agric. Environ. Sci. Coop. Ext. Spec. Bull. 41-08:11.

22. Kirk, W. D. J. 1997. Distribution, abundance, and population dynamics. Pages $217-258$ in: Thrips as Crop Pests. T. Lewis, ed. CAB, Wallingford, Oxon, UK.

23. Kirk, W. D. J. 2004. The link between cereal thrips and thunderstorms. Acta Phytopathol. Entomol. Hung. 39:13-16

24. Kuhn, M. 2008. Building predictive models in $\mathrm{R}$ using the caret package. J. Stat. Softw. 28:126

25. Lewis, T. 1964. The weather and mass flights of Thysanoptera. Ann. Appl. Biol. 53:165-170.

26. Lewis, T. 1965 . The species, aerial density and sexual maturity of Thysanoptera caught in mass flights. Ann. Appl. Biol. 55:219-225.

27. Lewis, T. 1973. Thrips: Their Biology, Ecology and Economic Importance. Academic Press, London.

28. Lewis, T. 1997. Flight and Dispersal. In: Thrips as Crop Pests. T. Lewis, ed. CAB, Wallingford, Oxon, UK

29. Lowry, V. K., Smith, J. W., Jr., and Mitchell, F. L. 1992. Life fertility tables for Frankliniella fusca and F. occidentalis on peanut. Ann. Entomol. Soc. Am. 85:744-754.

30. Makowskia, D., Taverneb, M., Bolomierb, J., and Ducarneb, M. 2005. Comparison of risk indicators for Sclerotinia control in oilseed rape. Crop Prot. 24:527-531.

31. Mandal, B., Pappu, H. R., and Culbreath, A. K 2001. Factors affecting mechanical transmission of Tomato spotted wilt virus to peanut (Arachis hypogaea). Plant Dis. 85:1259-1263.

32. McDonald, J. R., Bale, J. S., and Walters, K. F. A. 1998. Effect of temperature on development of the western flower thrips, Frankliniella occidentalis (Thysanoptera, Thripidae Thripidae). Eur. J. Entomol. 95:301-306

33. Mitchell, F. L., and Smith, J. W. Jr. 1991. Epidemiology of tomato spotted wilt virus relative to thrips populations. Virus-ThripsPlant Interactions of Tomato Spotted Wilt Virus. Proc. U. S. Dep. Agric. Workshop. USDAARS Bull. ARS 87:46-52.

34. Morsello, S. C. 2007. The role of temperature and precipitation on thrips populations in relation to the epidemiology of Tomato spotted wilt virus. Ph.D. thesis, Department of Entomology, North Carolina State University, Raleigh.

35. Morsello, S. C., Groves R. L., Nault B. A., and Kennedy, G. G. 2008. Temperature and precipitation affect seasonal patterns of dispersing tobacco thrips, Frankliniella fusca, and onion thrips, Thrips tabaci (Thysanoptera: Thripidae) caught on sticky traps. Environ. Entomol. 37:79-86

36. Olatinwo, R. O., Paz, J. O., Brown, S. L., Kemerait, R. C., Culbreath, A. K., Beasley, J. P., Jr., and Hoogenboom, G. 2008. A predictive model for spotted wilt epidemics in peanu based on local weather conditions and the Tomato spotted wilt virus risk index. Phytopathology 98:1066-1074.

37. Paul, P. A., and Munkvold, G. P. 2004. A model-based approach to preplanting risk assessment for gray leaf spot of maize. Phytopathology 94:1350-1357.

38. Pearsall, I. A., and Myers, J. H. 2001. Spatial and temporal patters of dispersal of western flower thrips (Thysanoptera: Thripidae) in nectarine orchards in British Columbia. J. Econ. Entomol. 94:831-843.

39. Todd, J. W., Culbreath, A. K., Chamberlin, J. R., Beshear, R. J., and Mullinix, B. J. 1995. Colonization and population dynamics of thrips in peanuts in the southern United States. Pages 453-460 in: Thrips Biology and Management. B. L. Parker, M. Skinner, and T. Lewis, eds. Plenum, New York.

40. Turechek, W. W., and Wilcox, W. F. 2005 Evaluating predictors of apple scab with receiver operating characteristic curve analysis. Phytopathology 95:679-691.

41. Yuen, J. E., and Hughes, G. 2002. Bayesian analysis of plant disease prediction. Plant Pathol. 51:407-412. 